\title{
The Effects of Community Empowerment on Preventing Dengue Fever in Lampung Province, Indonesia
}

\author{
Achmad Farich $^{1 \star}$, Nur Indrawati Lipoeto ${ }^{2}$, Hafni Bachtiar ${ }^{3}$, Hardisman Hardisman ${ }^{3}$ \\ ${ }^{1}$ Doctoral Prqogram, Faculty of Medicine, Universitas Andalas, Padang, West Sumatera Province, Indonesia; ${ }^{2}$ Department of \\ Nutrition, Faculty of Medicine, Universitas Andalas, Padang, West Sumatera Province, Indonesia; ${ }^{3}$ Department of Public Health \\ and Community Medicine, Faculty of Medicine, Universitas Andalas, Padang, West Sumatera Province, Indonesia
}

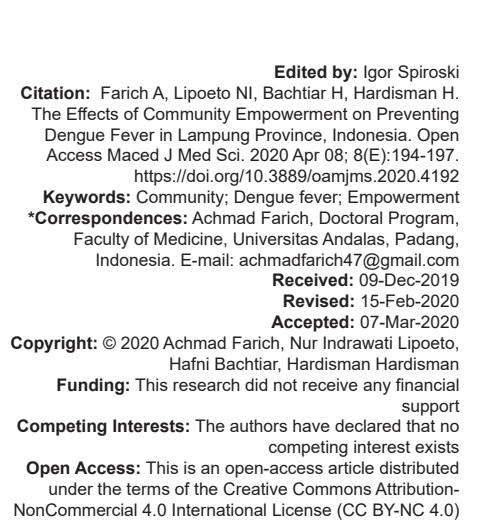

Abstract

AIM: The aim of this study was to determine the effects of community empowerment on preventing dengue fever in Lampung Province, Indonesia.

METHODS: This study used a quasi-experimental design with two groups of pretest-posttest design. The number of samples in this study was 120 people in the intervention group and 120 people in the control group, who is a housewife living in Gading Rejo and Pringsewu subdistrict, Lampung, Indonesia. The sampling technique used a proportional stratified random sampling technique. Community empowerment interventions have been carried out through socialization and inculturation to gather information about community participation, knowledge, attitudes, and behavior of respondents in the prevention of dengue fever. Then, the next stage is the implementation of interventions with capacity building and planting dengue mosquito repellent plants. Data were analyzed using Wilcoxon test using the SPSS version 21.0 software.

RESULTS: This study showed that there were differences in the median score of knowledge, attitudes, and behaviors between the intervention and control groups $(p<0.05)$. The results of the analysis based on the entomologist indicators (larvae-free numbers, house index, container index, and Breteau index) found that there were differences in larvae-free numbers, house index, and Breteau index between the intervention and control groups $(p<0.05)$, while there were no differences in the container index between the intervention and control groups $(p>0.05)$.

CONCLUSION: This study confirmed the effects of community empowerment on preventing dengue fever in Lampung Province, Indonesia.

\section{Introduction}

Dengue fever is still one of the major public health problems in Indonesia [1]. The number of dengue fever sufferers has reported in 2018 as many as 201,885 cases and the total death rate of 1585 people. The incidence rate (IR) was $77.96 / 100,000$ population and case fatality rate (CFR) was $0.79 \%$ [2]. An increase in dengue fever cases also occurred in Lampung Province which is one of the provinces in Indonesia with an IR was $74.86 / 100,000$ population and a CFR of $0.42 \%$ [3]. Lack of community participation in the activity of eradicating mosquito nests is one of the factors that make the spread of dengue virus easier and wider [4].

Community involvement in eradicating dengue is an important contribution and needs to be fostered to consciously live in a clean environment so as to prevent the proliferation of dengue fever vectors. Utilizing social capital bonding in rural areas as well as in urban areas is an attachment that makes it easy for them to empower, action and learning, both in urban and rural areas by linking the prevention of dengue fever with social bonding capital making it easier to increase bridging social capital for cooperation in the economic field so that it can be sustainable toward a healthy life [5].

The previous study found examined the level of community preparedness in the prevention and control of dengue in two different regions, namely, areas with low dengue fever and high dengue fever, it was found that the level of community readiness in areas with high dengue fever is better than areas with low dengue fever. The participatory approach allows local people to make dengue prevention efforts themselves [6]. Another study showed education and knowledge related to the incidence of dengue fever. The higher the level of education can increase knowledge. Good knowledge and understanding of dengue fever along with risk factors will be very helpful in reducing the incidence [7].

\section{Materials and Methods}

\section{Study design and research sample}

This study used a quasi-experimental design with two groups of pretest-posttest design. The 
number of samples in this study was 120 people in the intervention group and 120 people in the control group, who is a housewife living in Gading Rejo and Pringsewu subdistrict, Lampung, Indonesia. The sampling technique used a proportional stratified random sampling technique.

\section{Research procedure}

Community empowerment interventions have been carried out through socialization and inculturation to gather information about community participation, knowledge, attitudes, and behavior of respondents in the prevention of dengue fever. Then, the next stage is the implementation of interventions with capacity building and planting dengue mosquito repellent plants. This research has been through an ethical review by the ethics committee of the Faculty of Medicine, Universitas Andalas, Padang, Indonesia, with a number of 97/KEP/ FK/2018.

\section{Data analysis}

The analysis was performed frequency, percentage, and median score of knowledge, attitudes, and behavior of respondents in the prevention of dengue fever. $p<0.05$ was considered statistically significant. Data were analyzed using Wilcoxon test with SPSS version 21.0 software.

\section{Results}

Table 1 shows that most of the respondents in the intervention group (34.2\%) and the control group $(44.2 \%)$ had an educational background that was senior high school. More than half of respondents (59.1\%) in the intervention group did not work and less than half of respondents $(40.9 \%)$ in the control group.

Table 1: Characteristics of the study subjects

\begin{tabular}{|c|c|c|c|c|}
\hline \multirow[t]{3}{*}{ Variables } & \multicolumn{4}{|c|}{ Group } \\
\hline & \multicolumn{2}{|c|}{ Intervention } & \multicolumn{2}{|c|}{ Control } \\
\hline & $f$ & $\%$ & $f$ & $\%$ \\
\hline \multicolumn{5}{|l|}{ Age (years) } \\
\hline \multicolumn{5}{|c|}{ Educational background } \\
\hline No school & 11 & 9.2 & 5 & 4.2 \\
\hline Elementary school & 29 & 24.2 & 34 & 28.3 \\
\hline Junior high school & 33 & 27.5 & 23 & 19.2 \\
\hline Senior high school & 41 & 34.2 & 53 & 44.2 \\
\hline Bachelor degree & 6 & 5 & 5 & 4.2 \\
\hline \multicolumn{5}{|l|}{ Working status } \\
\hline Private servant & 4 & 3.3 & 6 & 5.0 \\
\hline Entrepreneur & 23 & 19.2 & 21 & 17.5 \\
\hline Laborers & 22 & 18.3 & 44 & 36.7 \\
\hline Not working & 71 & 59.1 & 49 & 40.9 \\
\hline
\end{tabular}

Table 2 shows that there were differences in the median score of knowledge, attitudes, and behaviors between the intervention and control groups $(p<0.05)$.
Table 2: Median score differences in knowledge, attitudes, and behaviors before and after community empowerment on preventing dengue fever

\begin{tabular}{lllll}
\hline Variables & $\mathrm{f}$ & Median (min-max) & $\Delta$ Median scores & $\mathrm{p}$-value \\
\hline Knowledge & & & 4.0 & $0.001^{*}$ \\
$\quad$ Before & 120 & $5.0(0-12)$ & & \\
$\quad$ After & 120 & $9.0(4-12)$ & & $0.001^{*}$ \\
Attitude & & & 3.0 & \\
$\quad$ Before & 120 & $6.0(0-11)$ & & $0.001^{*}$ \\
$\quad$ After & 120 & $9.0(5-12)$ & 2.0 & \\
Behavior & & & & \\
$\quad$ Before & 120 & $9.0(0-13)$ & & \\
$\quad$ After & 120 & $11.0(9-13)$ & & \\
${ }^{*} p<0.05$, significant. & & &
\end{tabular}

Table 3 shows that the entomologist data analysis was obtained in the intervention group before the intervention of entomological indicators of LFN was $50.8 \%$ included in the high transmission category, $\mathrm{HI}$ was $49.1 \%$ included in the high-risk category, $\mathrm{Cl}$ was $10.9 \%$ included in the high-risk category, and $\mathrm{BI}$ was $90 \%$ included in the high-risk category.

The intervention group after community empowerment on preventing dengue fever, it was found that the entomology indicators of LFN increased were $96.6 \%$ included in the category of no transmission, $\mathrm{HI}$ decreased were $3.33 \%$ included in the low-risk category, $\mathrm{Cl}$ decreased were $0.18 \%$ included in the lowrisk category, and $\mathrm{BI}$ decreased were $3.33 \%$ included in the low-risk category.

Table 4 shows based on the entomologist indicators (larvae-free numbers, house index, container index, and Breteau index) found that there were differences in larvae-free numbers, house index, and Breteau index between the intervention and control groups $(p<0.05)$, while there were no differences in the container index between the intervention and control groups $(p>0.05)$.

\section{Discussion}

The results of the study showed that there were differences in the median score of knowledge, attitudes, and behaviors between the intervention and control groups. The results of the analysis based on the entomologist indicators (larvae-free numbers, house index, container index, and Breteau index) found that there were differences in larvae-free numbers, house index, and Breteau index between the intervention and control groups, while there were no differences in the container index between the intervention and control groups.

Several previous studies have shown that knowledge, attitudes, and behaviors are interconnected components and affect perceptions about dengue fever, preventive measures, and risk factors for dengue transmission. Another research also states that community empowerment, capacity building, campaign, or community-based movements have succeeded 
Table 3: Distribution of entomologist indicators before and after community empowerment on preventing dengue fever in the intervention and control groups

\begin{tabular}{|c|c|c|c|c|}
\hline & \multicolumn{4}{|l|}{ Entomologist indicators } \\
\hline & MLFN & $\mathrm{HI}$ & $\mathrm{Cl}$ & $\mathrm{BI}$ \\
\hline \multicolumn{5}{|l|}{ Pre-test } \\
\hline Intervention group & 50.8\% (high transmission) & $49.1 \%$ (high risk) & $10.9 \%$ (high risk) & $90 \%$ (high risk) \\
\hline Control group & $75.8 \%$ (moderate transmission) & $24.1 \%$ (high risk) & $3.04 \%$ (low risk) & $59.16 \%$ (high risk) \\
\hline \multicolumn{5}{|l|}{ Post-test } \\
\hline Intervention group & 96.6\% (no transmission) & $3.33 \%$ (low risk) & $0.18 \%$ (low risk) & $3.33 \%$ (low risk) \\
\hline Control group & $80 \%$ (moderate transmission) & $20 \%$ (high risk) & $6.35 \%$ (low risk) & $30.8 \%$ (low risk) \\
\hline
\end{tabular}

Table 4: Differences in entomologist indicators before and after community empowerment on preventing dengue fever in the intervention and control groups

\begin{tabular}{llll}
\hline Variables & Mean & $\Delta$ Mean & p-value \\
\hline LFN & & -0.408 & 0.001 \\
$\quad$ Intervention group & -0.491 & & \\
Control group & -0.083 & -0.408 & 0.001 \\
$\mathrm{HI} \quad$ Intervention group & -0.491 & & \\
$\quad$ Control group & -0.083 & -4.867 & 0.698 \\
$\mathrm{Cl}$ & -6.692 & & \\
$\quad$ Intervention group & -11.55 & -0.483 & 0.001 \\
$\quad$ Control group & -0.883 & & \\
$\mathrm{BI} \quad$ Intervention group & -0.400 & & \\
$\quad$ Control group & &
\end{tabular}

${ }^{*} \mathrm{p}<0.05$, significant.

in reducing entomological indicators, namely, $\mathrm{HI}, \mathrm{Cl}$, and $\mathrm{BI}[8]$, [9], [10].

The previous studies reinforced the method of preventing dengue transmission which was emphasized by the World Health Organization (WHO) to eradicate the infectious mosquitoes, including through management and environmental modification, waste management dense, vector surveillance, participation, community mobilization, and others [11].

Health promotion is an effort to make changes in people's behavior, to change lifestyle and quality of life through changes in individuals and a better environment. The global strategy for health promotion includes empowerment and community participation. The purpose of empowerment is to increase the capacity and capability of the community to be able to recognize the problems faced, be able to explore and utilize resources that are available, and able to exist clearly. Participation is voluntary involvement by the community in self-determined changes, which can also mean community involvement in self-development, life, and environment [12].

Dengue fever control is done by building community trust, community education about dengue, building community programs, organizing communities, and running programs with the community on an ongoing basis. This community empowerment can be done in various ways adapted to the conditions of society. Communities are invited together to identify problems related to dengue fever, determine programs that can be implemented, carry out programs to monitor, and evaluate the implementation of dengue control.

The failure of some efforts to control dengue fever to date can be used as a lesson that the process of controlling dengue cannot run alone. There must be a very good cooperative relationship between the government, the Ministry of Health, and other institutions with the community. The government that has the program but who runs it is the community, if the community is not given enough provisions to implement the program, then the sustainability of the program will not be possible.

\section{Conclusion}

This analysis confirmed an effects of community empowerment on preventing dengue fever in Lampung Province, Indonesia.

\section{Acknowledgments}

The author would like to thank all respondents involved in this study.

\section{References}

1. Ministry of Health of Republic of Indonesia. Indonesia Basic Health Research. Jakarta: Ministry of Health of Republic of Indonesia; 2018. https://doi.org/10.25133/jpssv27n1.003

2. Ministry of Health of Republic of Indonesia. Indonesia Basic Health Research. Jakarta: Ministry of Health of Republic of Indonesia; 2013. https://doi.org/10.25133/jpssv27n1.003

3. Harapan H, Michie A, Mudatsir M, Sasmono RT, Imrie A. Epidemiology of dengue hemorrhagic fever in Indonesia: Analysis of five decades data from the national disease surveillance. BMC Res Notes. 2019;12:350. https://doi. org/10.1186/s13104-019-4379-9

4. Therawiwat M, Fungladda W, Kaewkungwal J, Imamee N, Steckler A. Community-based approach for prevention and control of dengue hemorrhagic fever in Kanchanaburi Province, Thailand. Southeast Asian J Trop Med Public Health. 2005;36(6):1439-49.

5. Prayitno A, Taurel AF, Nealon J, Satari HI, Karyanti MR, Sekartini $R$, et al. Dengue seroprevalence and force of primary infection in a representative population of urban dwelling Indonesian children. PLoS NegI Trop Dis. 2017;11(6):e0005621. https://doi.org/10.1371/journal.pntd.0006467

PMid:28617803 
6. Rakhmani AN, Limpanont $\mathrm{Y}$, Kaewkungwal J, Okanurak K. Factors associated with dengue prevention behaviour in Lowokwaru, Malang, Indonesia: A cross-sectional study. BMC Public Health. 2018;18:619. https://doi.org/10.1186/ s12889-018-5553-Z

PMid:29751758

7. Shuaib F, Todd D, Campbell-Stennett D, Ehiri J, Jolly PE. Knowledge, attitudes and practices regarding dengue infection in Westmoreland, Jamaica. West Indian Med J. 2010;59(2):139-46.

8. Chanyasanha C, Guruge GR, Sujirarat D. Factors influencing preventive behaviors for dengue infection among housewives in Colombo, Sri Lanka. Asia Pac J Public Health. 2015;27(1):96-104. https://doi.org/10.1177/1010539514545646 PMid:25155069

9. Hairi $\mathrm{F}$, Ong $\mathrm{CH}$, Suhaimi A, Tsung TW, bin Anis Ahmad MA, Sundaraj $\mathrm{C}$, et al. A knowledge, attitude and practices (KAP) study on dengue among selected rural communities in the Kuala
Kangsar District. Asia Pac J Public Health. 2003;15(1):37-43. https://doi.org/10.1177/101053950301500107

PMid:14620496

10. Harapan H, Rajamoorthy $\mathrm{Y}$, Anwar S, Bustamam A, Radiansyah A, Angraini $\mathrm{P}$, et al. Knowledge, attitude, and practice regarding dengue virus infection among inhabitants of Aceh, Indonesia: A cross-sectional study. BMC Infect Dis. 2018;18(1):96. https://doi.org/10.1186/s12879-018-3006-z PMid:29486714

11. World Health Organization. Global Strategy for Dengue Prevention and Control, 2012-2020. Geneva: WHO Press; 2012.

12. Koenraadt C, Tuiten W, Sithiprasasna R, Kijchalao U, Jones JW, Scott TW. Dengue knowledge and practices and their impact on Aedes aegypti populations in Kamphaeng Phet, Thailand. Am J Trop Med Hyg. 2006;74(4):692-700. https://doi.org/10.4269/ ajtmh.2006.74.692

PMid: 16607007 